Article

\title{
New Hybrid Tomato Cultivars: An NMR-Based Chemical Characterization
}

\author{
Cinzia Ingallina ${ }^{1}{ }^{\circledR}$, Anatoly P. Sobolev ${ }^{2, *}$, Simone Circi ${ }^{1}$, Mattia Spano ${ }^{1}$, \\ Anna Maria Giusti ${ }^{3}$ (D) and Luisa Mannina ${ }^{1,2} \mathbb{D}$ \\ 1 Dipartimento di Chimica e Tecnologie del Farmaco, Sapienza Università di Roma, P.le Aldo Moro 5, \\ 00185 Rome, Italy; cinzia.ingallina@uniroma1.it (C.I.); simone.circi@uniroma1.it (S.C.); \\ mattia.spano@uniroma1.it (M.S.); luisa.mannina@uniroma.it (L.M.) \\ 2 Istituto per i Sistemi Biologici, Laboratorio di Risonanza Magnetica "Segre-Capitani", CNR, Monterotondo, \\ 00015 Rome, Italy \\ 3 Dipartimento di Medicina Sperimentale, Sapienza Università di Roma, P.le Aldo Moro 5, 00185 Rome, Italy; \\ annamaria.giusti@uniroma1.it \\ * Correspondence: anatoly.sobolev@cnr.it; Tel.: +39-06-90672385
}

Received: 11 February 2020; Accepted: 6 March 2020; Published: 10 March 2020

Featured Application: The knowledge of the hybrid tomatoes metabolite profile represents an important tool for fresh market, industries, and customers, driving them to a more targeted and valorized use of the fruits.

\begin{abstract}
Bamano, King Creole, Sugarland, and DulceMiel hybrid tomato cultivars have been recently introduced in the Lazio area (Central Italy) to expand and valorize the regional/national market. Tomatoes from these cultivars, together with tomatoes from the native Fiaschetta cultivar, were sampled at the proper ripening time for the fresh market and characterized to obtain and compare their metabolite profiles. The Bligh-Dyer extraction protocol was carried out, and the resulting organic and hydroalcoholic fractions were analyzed by high-field Nuclear Magnetic Resonance (NMR) spectroscopy. NMR data relative to quantified metabolites (sugars, amino acids, organic acids, sterols, and fatty acids) allowed to point out similarities and differences among cultivars. DulceMiel hybrid and Fiaschetta native cultivars showed some common aspects having the highest levels of the most abundant amino acids as well as comparable amounts of organic acids, amino acids, stigmasterol, and linoleic and linolenic acids. However, DulceMiel turned out to have higher levels of glucose, fructose, and galactose with respect to Fiaschetta, reflecting the particular taste of the DulceMiel product. King Creole, Bamano, and Sugarland hybrid cultivars were generally characterized by the lowest content of amino acids and organic acids. King Creole showed the highest content of malic acid, whereas Bamano was characterized by the highest levels of glucose and fructose.
\end{abstract}

Keywords: hybrid tomato; ${ }^{1} \mathrm{H}-\mathrm{NMR}$; metabolic profile

\section{Introduction}

Tomatoes (Lycopersicum esculentum) represent the most consumed vegetables worldwide grown for both fresh consumption and processing (mainly to make tomato paste), thus identifying two different industry segments. According to statistics [1], 182 million tons of tomatoes were globally grown in 2017, 25 million tons being produced in Europe. Forty percent of the European tomatoes are sold on the fresh market. Today, Italy represents the first major European producer (followed by Spain), capable of providing 6 million tons of product per year.

In the last two decades, breeding programs and hybrid seed production have been addressed to enhance plant tolerance to abiotic and biotic stresses, fruit nutritional value, and fruit quality [2]. 
Duvick [3] has reported that in the USA, as well as in most European, Asian, and Australian countries, the majority of tomato production (100\% of fresh market and $80 \%$ of processing tomatoes) is obtained with hybrids [2]. Hybrid tomato cultivars are more frequently used than the open pollinated lines thanks to advantages such as high productivity, early maturation, high fruit uniformity, high fruit quality, and disease resistance. Tomato hybrid production often gives plants with desirable characteristics superior with respect to the native ones but, at the same time, the production of hybrid seeds is generally not easy and laborious [2].

Tomato features such as taste and fragrance as well as healthful properties depend on the fruit chemical composition. For instance, sugars are responsible for different sweetness levels; organic acids are correlated with sourness; amino acids such as glutamate, glutamine, and aspartate enhance the bitterness [4,5]; whereas glutamic acid seems to be correlated to umami taste [6].

Among different analytical methods, high-resolution Nuclear Magnetic Resonance (NMR) spectroscopy is one of the most suitable approaches to monitor the composition of foodstuffs, owing to its ability to identify and quantify major and minor components without physical separation in the same experiment $[7,8]$. The NMR metabolomic approach has been largely used to characterize tomatoes fruits and derived products. Besides the identification of principal components such as sugars, organic acids, amino acids, and minor components [9-12], several studies have been carried out to determine carotenoid composition [13], degree of ripeness [14-17], geographical origin [18], and sensory features [4,5,19]; to compare organic and conventional tomatoes [20]; and to evaluate genetic transformations [21,22].

Within the regional project titled "eALIERB: an OPEN LAB to characterize and valorize foodstuffs and botanicals of Lazio region", the chemical composition of hybrid tomatoes namely Bamano, DulceMiel, Sugarland, and King Creole cultivars together with the native Italian Fiaschetta di Fondi cultivar was investigated for the first time. These hybrid cultivars have been recently introduced in the Lazio region (Central Italy) aiming at expanding the regional agronomic fresh market with products characterized by peculiar sensorial and nutritional features useful for industries and customers. In this paper, the NMR-based characterization of Bamano, DulceMiel, Sugarland, and King Creole hybrid cultivars together with the native Italian Fiaschetta di Fondi cultivar was carried out to obtain and compare their metabolite profiles.

\section{Materials and Methods}

\subsection{Sampling}

Tomatoes from four hybrid cultivars (Figure 1) namely Bamano, DulceMiel, Sugarland RZ F1, and King Creole and one native Fiaschetta di Fondi cultivar were cultivated in the southern area of the Lazio region (Fondi, LT) and collected by the "Terra del Sole" local farm. Tomatoes were cultivated within a greenhouse, without climate control systems, and were collected by hand during July according to their ripening degree proper for the market. Tomato seeds were provided by Syngenta, Basel, Switzerland (Bamano, DulceMiel and King Creole), Rijk Zwaan, De Lier, Netherlands (Sugarland RZ F1), and Terra del Sole, Fondi, Latina, Italy (Fiaschetta di Fondi) farms. 

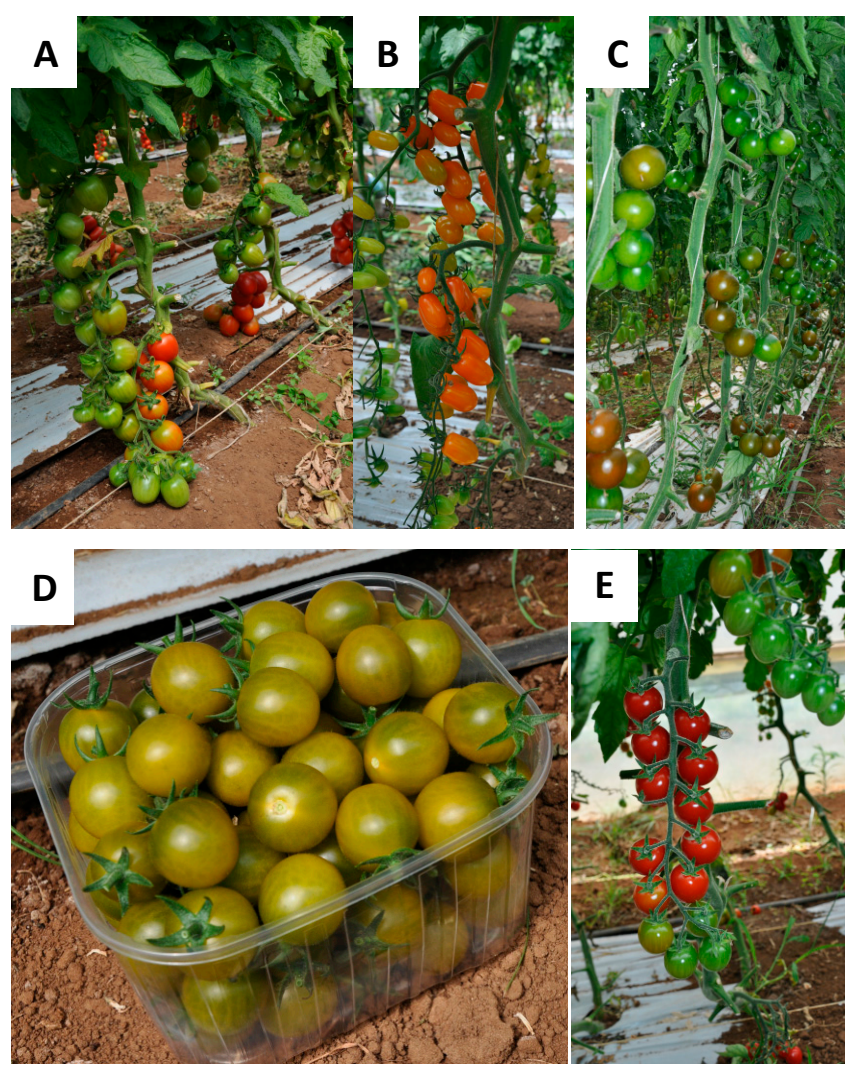

Figure 1. Tomato cultivars from Fondi area (Lazio region): (A) Fiaschetta di Fondi; (B) Bamano; (C) King Creole; (D) DulceMiel; (E) Sugarland.

\subsection{Tomatoe Cultivars}

Bamano tomatoes (Figure 1B) are uniform orange fruits (weight 10-12 g) with a consistent shape. King Creole fruits (Figure 1C, weight 30-40 g) are green in color, turning to dark red-brown when mature, and round in shape. Sugarland RZ F1 (Figure 1E) represents a cherry cultivar with small fruits, deep shiny red in color. DulceMiel (Figure 1D) is a sweet and aromatic cultivar characterized by green color, with honey shades when it is mature, oval in shape (weight 14-16 g). Fiaschetta di Fondi (Figure 1A) is a native tomato officially recognized in 2017 as a traditional agricultural product ("TAP") by the Italian Ministry of Agriculture. Fiaschetta belongs to Lycopersicon esculentum (L.) species, local ecotype "Fiaschetta di Fondi". It is characterized by a flask shape, deep and uniform red color (weight $40 \mathrm{~g}$ ). The peel is consistent, and the pulp has a unique sweet-sour taste with a Brix grade of 5 .

\subsection{Extraction Procedure}

Fifteen fresh tomatoes for each cultivar were frozen and ground in liquid nitrogen to obtain a homogeneous pool subjected to the Bligh-Dyer procedure. In detail, sequentially, $3 \mathrm{~mL}$ of methanol/chloroform (2:1 v/v) mixture, $1 \mathrm{~mL}$ of chloroform, and $1.2 \mathrm{~mL}$ of distilled water was added to about $1.0 \mathrm{~g}$ of homogenized tomatoes from each cultivar. After each addition, the sample was carefully shaken. The emulsion was preserved at $4{ }^{\circ} \mathrm{C}$ for $40 \mathrm{~min}$. The sample was then centrifuged (4200 $\mathrm{g}$ for $15 \mathrm{~min}$ at $4{ }^{\circ} \mathrm{C}$ ), and the hydroalcoholic and organic phases were carefully separated. The pellets were re-extracted using half of the solvent volumes (in the same conditions described above), and the separated fractions were pooled. Both fractions were dried under a gentle $\mathrm{N}_{2}$ flow at room temperature until the solvent was completely evaporated. The dried phases were stored at $-20{ }^{\circ} \mathrm{C}$ until further analyses [23]. 


\subsection{NMR Analyses}

The dried organic fraction of each sample was dissolved in $0.7 \mathrm{~mL}$ of a $\mathrm{CDCl}_{3} / \mathrm{CD}_{3} \mathrm{OD}$ mixture $(2: 1 v / v)$ and then placed into a $5 \mathrm{~mm}$ NMR tube. Finally, the NMR tube was flame sealed. Conversely, the dried hydroalcoholic phase of each sample was solubilized in $0.7 \mathrm{~mL} 400 \mathrm{mM}$ phosphate buffer $/ \mathrm{D}_{2} \mathrm{O}$ containing $1 \mathrm{mM}$ solution of TSP as internal standard and then transferred into a $5 \mathrm{~mm}$ NMR tube. NMR spectra of all hydroalcoholic and organic extracts were recorded at $27^{\circ} \mathrm{C}$ on a Bruker AVANCE 600 spectrometer operating at the proton frequency of $600.13 \mathrm{MHz}$ and equipped with a Bruker multinuclear z-gradient $5 \mathrm{~mm}$ probe head. ${ }^{1} \mathrm{H}$ spectra were referenced to methyl group signals of TSP $\left(\delta=0.00 \mathrm{ppm}\right.$ ) in $\mathrm{D}_{2} \mathrm{O}$ and to the residual $\mathrm{CHD}_{2}$ signal of methanol (set to $3.31 \mathrm{ppm}$ ) in $\mathrm{CD}_{3} \mathrm{OD} / \mathrm{CDCl}_{3}$ mixture. ${ }^{1} \mathrm{H}$ spectra of hydroalcoholic extracts were acquired with 256 transients with a recycle delay of $5 \mathrm{~s}$. The residual HDO signal was suppressed using a pre-saturation. The experiment was carried out by using $45^{\circ}$ pulse of 6.5-7.5 $\mu \mathrm{s}, 32 \mathrm{~K}$ data points. ${ }^{1} \mathrm{H}$ spectra of extracts in $\mathrm{CD}_{3} \mathrm{OD} / \mathrm{CDCl}_{3}$ were acquired with 256 transients, recycle delay of $5 \mathrm{~s}$, and $90^{\circ}$ pulse of $9-11 \mu \mathrm{s}, 32 \mathrm{~K}$ data points. The two-dimensional (2D) NMR experiments, such as ${ }^{1} \mathrm{H}_{-}{ }^{1} \mathrm{H}$ TOCSY, ${ }^{1} \mathrm{H}_{-}{ }^{13} \mathrm{C}$ HSQC, and ${ }^{1} \mathrm{H}_{-}{ }^{13} \mathrm{C} \mathrm{HMBC}$, were carried out under the same experimental conditions previously reported [24]. The integrals of 25 selected signals in hydroalcoholic extract (Table 1) were measured using the Bruker TOPSPIN software and normalized with respect to the resonance at $0.00 \mathrm{ppm}$, due to methyl group signal of TSP, normalized to 100 . Results have been expressed in $\mathrm{mg} / 100 \mathrm{~g}$ FW. The integrals of 6 selected signals in organic extract (Table 2) were also measured using the Bruker TOPSPIN software and normalized with respect to the resonance at $2.30 \mathrm{ppm}$, due to signal of total fatty acids, set to 100 . The molar $\%$ values of fatty acids and sterols were calculated using the following equations:

$$
\begin{gathered}
\%_{\beta-S I T}=100 \times 0.66 \mathrm{I}_{\beta-\mathrm{SIT}} / \mathrm{I}_{\text {tot }} \\
\%_{\mathrm{STIG}}=100 \times 0.66 \mathrm{I}_{\mathrm{STIG}} / \mathrm{I}_{\mathrm{tot}} \\
\%_{\mathrm{TRI}}=100 \times 0.5 \mathrm{I}_{\mathrm{TRI}} / \mathrm{I}_{\text {tot }} \\
\%_{\mathrm{DI}}=100 \times \mathrm{I}_{\mathrm{DI}} / \mathrm{I}_{\mathrm{tot}} \\
\%_{\mathrm{MONO}}=100 \times\left(\mathrm{I}_{\mathrm{UNS}}-2 \mathrm{I}_{\mathrm{Di}}-1.5 \mathrm{I}_{\mathrm{TRI}}\right) / \mathrm{I}_{\text {tot }} \\
\%_{\mathrm{SAT}}=100 \times\left(\mathrm{I}_{\mathrm{FA}}-\mathrm{I}_{\mathrm{DI}}-0.5 \mathrm{I}_{\mathrm{TRI}}-\mathrm{I}_{\mathrm{MONO}}\right) / \mathrm{I}_{\text {tot }}
\end{gathered}
$$

where $\%_{\beta}$-SIT, $\%_{\text {STIG }}, \%_{\text {TRI }}, \%_{\text {DI }}, \%_{\text {MONO }}, \%_{\text {SAT }}$ are molar $\%$ of $\beta$-sitosterol, stigmasterol, tri-unsaturated fatty acids, di-unsaturated fatty acids, mono-unsaturated fatty acids, and saturated fatty acids, respectively. $\mathrm{I}_{\beta-S I T}, \mathrm{I}_{\mathrm{STIG}}, \mathrm{I}_{\mathrm{TRI}}, \mathrm{I}_{\mathrm{DI}}, \mathrm{I}_{\mathrm{UNS}}, \mathrm{I}_{\mathrm{FA}}$ are integrals (see Table 2 ), and $\mathrm{I}_{\text {tot }}$ is calculated according to the Equation (7)

$$
\mathrm{I}_{\mathrm{tot}}=\mathrm{I}_{\mathrm{FA}}+0.66 \mathrm{I}_{\beta-\mathrm{SIT}}+0.66 \mathrm{I}_{\mathrm{STIG}}
$$

Table 1. Compounds and relative signals (ppm) selected for quantitative analysis in the hydroalcoholic extracts.

\begin{tabular}{cccc}
\hline ppm & Compounds & ppm & Compounds \\
\hline 0.96 & Leu & 3.21 & Choline \\
0.99 & Val & 3.25 & $\beta$-Glucose \\
1.01 & Ile & 4.04 & Fructose \\
1.33 & Lactic acid & 4.31 & Malic Acid \\
1.34 & Thr & 4.59 & $\beta$-Galactose \\
1.49 & Ala & 5.25 & $\alpha$-Glucose \\
2.30 & GABA & 6.91 & Tyr \\
2.35 & Glu & 7.34 & Phe \\
2.46 & Gln & 7.74 & Trp \\
2.55 & Citric Acid & 8.46 & Formic Acid \\
2.81 & Asp & 9.13 & Trigonelline \\
2.90 & Asn & & \\
\hline
\end{tabular}


Table 2. Compounds and relative signals (ppm) selected for quantitative analysis in the organic extracts.

\begin{tabular}{cccc}
\hline & ppm & Group & Compounds \\
\hline $\mathrm{I}_{\beta-\text { SIT }}$ & 0.66 & $\mathrm{CH}_{3}$ & $\beta$-Sitosterol \\
$\mathrm{I}_{\text {STIG }}$ & 0.68 & $\mathrm{CH}_{3}$ & Stigmasterol \\
$\mathrm{I}_{\mathrm{FA}}$ & 2.30 & $\alpha-\mathrm{CH}_{2}$ & Total fatty acids \\
$\mathrm{I}_{\text {DI }}$ & 2.73 & $\mathrm{CH}_{2}$ & Di-unsaturated fatty acids \\
$\mathrm{I}_{\text {TRI }}$ & 2.77 & $\mathrm{CH}_{2}$ & Tri-unsaturated fatty acids \\
$\mathrm{I}_{\text {UNS }}$ & 5.31 & $\mathrm{CH}=\mathrm{CH}$ & Total unsaturated fatty acids \\
\hline
\end{tabular}

\subsection{Tree Clustering Analysis}

Statistical analysis of the NMR data was carried out using STATISTICA software (version 5.1). Before performing the Tree Clustering Analysis, all the selected variables were mean-centered, and each variable was divided by its standard deviation (autoscaling). For Tree Clustering Analysis [25] the Euclidean distance, Equation (8), was used as a measure of distance between samples. For the measure of distance between clusters the complete linkage method was used (when the distance between clusters is determined using the greatest distance between any two objects in the different clusters):

$$
\text { distance }(\mathrm{x}, \mathrm{y})=\left[\Sigma_{\mathrm{i}}\left(\mathrm{x}_{\mathrm{i}}-\mathrm{y}_{\mathrm{i}}\right)^{2}\right]^{1 / 2}
$$

\section{Results}

The results of the NMR analysis regarding the tomato hydroalcoholic and organic fractions will be reported separately.

\subsection{Tomato Hydroalcoholic Fraction}

The 1D NMR spectrum assignment of the hydroalcoholic extracts solubilized in $\mathrm{D}_{2} \mathrm{O}$ phosphate buffer (data not reported) was obtained using literature data $[11,16,17]$ and confirmed by 2D experiments (Figures S1-S3). Compounds and relative NMR signals selected for quantitative analysis are reported in Table 1.

The amino acid profiles (Figure 2A) of the five cultivars showed some common aspects: GABA, alanine, glutamine, and glutamic acid were always the most abundant amino acids [6,26-28]. In particular, glutamic acid was the most abundant amino acid in all cultivars. On the other hand, valine, isoleucine, tyrosine, tryptophan, and leucine were always present at lower levels with respect to other amino acids. Concerning the difference among the cultivars, glutamic acid showed significant variations reaching $447 \mathrm{mg} / 100 \mathrm{~g}$ in DulceMiel cultivar, at least double with respect to the other cultivars. DulceMiel cultivar was also the cultivar with the major content of leucine, aspartic acid, and alanine. Fiaschetta cultivar showed a higher level of isoleucine, tyrosine, asparagine, GABA, and glutamine with respect to the others. Valine, tryptophan, threonine, and phenylalanine were found to be more abundant in Sugarland. Bamano and King Creole cultivars were characterized by a lower content of amino acids compared to the other samples.

Citric, malic, lactic, and formic acids were detected and quantified in all five cultivars with citric acid as the most abundant organic acid [17,29,30] (Figure 2B). DulceMiel cultivar showed the highest content of citric acid $(460 \mathrm{mg} / 100 \mathrm{~g})$ whereas King Creole showed an almost double malic acid content with respect to the other tomato cultivars. Formic acid was always present in minor amount being lower than $1.1 \mathrm{mg} / 100 \mathrm{~g}$. Fiaschetta cultivar was characterized by high lactic acid level $(26.5 \mathrm{mg} / 100 \mathrm{~g})$, at least 3.5-fold higher than in the other cultivars and more than doubled with respect to malic acid content $(10.4 \mathrm{mg} / 100 \mathrm{~g})$, which is known to be, together with citric acid, one of the most abundant organic acid in tomatoes $[11,20,21]$. Note that lactic acid has been rarely detected and not always quantified in tomato fruits $[14,30]$. The presence of higher amount of lactic acid in Fiachetta cultivar could be ascribed to the fermentation of tomato pulp by the bacteriocin-producing lactic acid bacteria [31,32].

Fructose was the most abundant sugar in all tomato fruits $[5,10,12,17,21]$, followed by glucose and galactose. DulceMiel, Bamano, and Sugarland cultivars showed the highest levels of fructose, 
galactose, and glucose, whereas both King Creole and Fiaschetta cultivars were characterized by the lowest levels, nearly halved with respect to the other cultivars (Figure 2C). These data suggest that Fiaschetta and King Creole cultivars could be useful in hypoglycemic diet.

Regarding the content of other metabolites (Figure 2D), the concentration of choline ranged from $6.9 \mathrm{mg} / 100 \mathrm{~g}$ in King Creole to $15.4 \mathrm{mg} / 100 \mathrm{~g}$ in DulceMiel cultivar, whereas trigonelline content was found to be lower than $2.5 \mathrm{mg} / 100 \mathrm{~g}$, varying from $0.9 \mathrm{mg} / 100 \mathrm{in}$ King Creole to $2.4 \mathrm{mg} / 100 \mathrm{~g}$ in Fiaschetta.

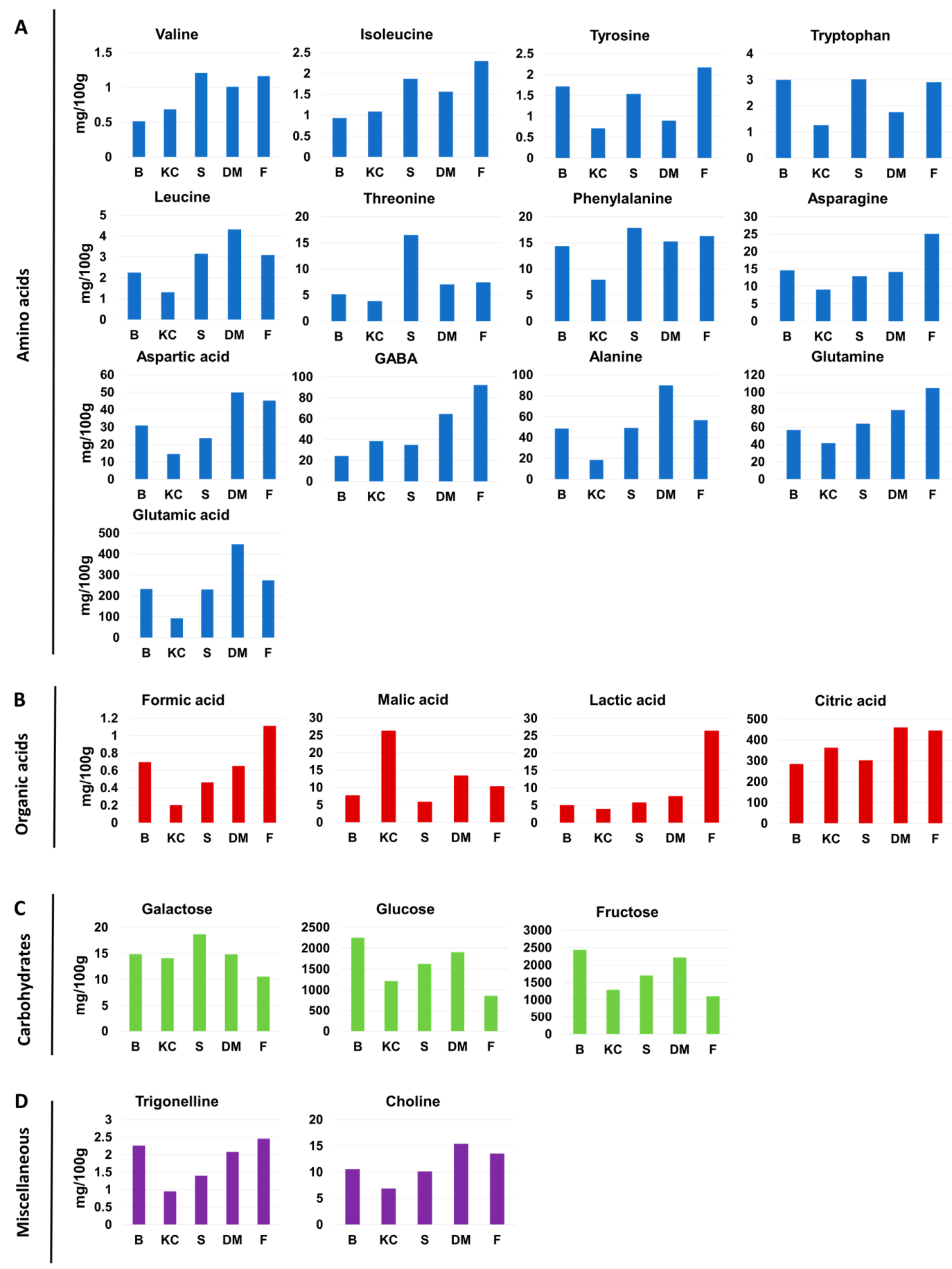

Figure 2. Histograms comparing the level of metabolites present in tomato hydroalcoholic extracts from the five investigated cultivars: (A) Amino acids; (B) Organic acids; (C) Carbohydrates; (D) Miscellaneous (B: Bamano, KC: King Creole, S: Sugarland, DM: DulceMiel, F: Fiaschetta). Data shown are expressed as $\mathrm{mg} / 100 \mathrm{~g}$ FW. 


\subsection{Tomato Organic Fraction}

The ${ }^{1} \mathrm{H}$ and ${ }^{13} \mathrm{C}$ NMR assignments of Bamano, King Creole, DulceMiel, Sugarland, and Fiaschetta tomatoes extracts in $\mathrm{CDCl}_{3} / \mathrm{CD}_{3} \mathrm{OH}$ was obtained by $2 \mathrm{D}$ experiments (Figures S4-S6). In Table 3, the metabolites identified in the tomatoes organic fraction are reported along with the assignment of ${ }^{1} \mathrm{H}$ and corresponding ${ }^{13} \mathrm{C}$ resonances. Previously, the ${ }^{1} \mathrm{H}$ NMR spectra assignment of organic fraction from lyophilized cherry tomatoes (Naomi and Shiren cultivars) in $\mathrm{CDCl}_{3}$ has been reported $[9,14]$. Taking into account different plant material, a different extraction procedure, and a different solvent $\left(\mathrm{CDCl}_{3} / \mathrm{CD}_{3} \mathrm{OH}\right.$ instead of $\left.\mathrm{CDCl}_{3}\right)$ used in the present study, a new ${ }^{1} \mathrm{H}$ NMR spectra assignment was required.

In the upfield spectral region, the $\mathrm{CH}_{3}-18$ signals of $\beta$-sitosterol at $0.66 \mathrm{ppm}$ ( $\mathrm{I}_{\beta \text {-SIT }}$ ), and stigmasterol at $0.68 \mathrm{ppm}\left(\mathrm{I}_{\text {STIG }}\right.$ ) were detected and quantified (Table 3 and Figures 3 and 4). The resonance centered at $2.30 \mathrm{ppm}\left(\mathrm{I}_{\mathrm{FA}}\right)$ was ascribed to $\alpha-\mathrm{CH}_{2}$ of all fatty acid chains. Resonances at $2.73\left(\mathrm{I}_{\mathrm{DI}}\right)$ and $2.77 \mathrm{ppm}\left(\mathrm{I}_{\mathrm{TRI}}\right)$ were ascribed to diallylic $\mathrm{CH}_{2}$ of linoleic and linolenic acids. The multiplet at 5.31 ppm (I $\mathrm{I}_{\mathrm{UNS}}$ ) belongs to double bond $\mathrm{CH}$ groups of all unsaturated fatty acids.

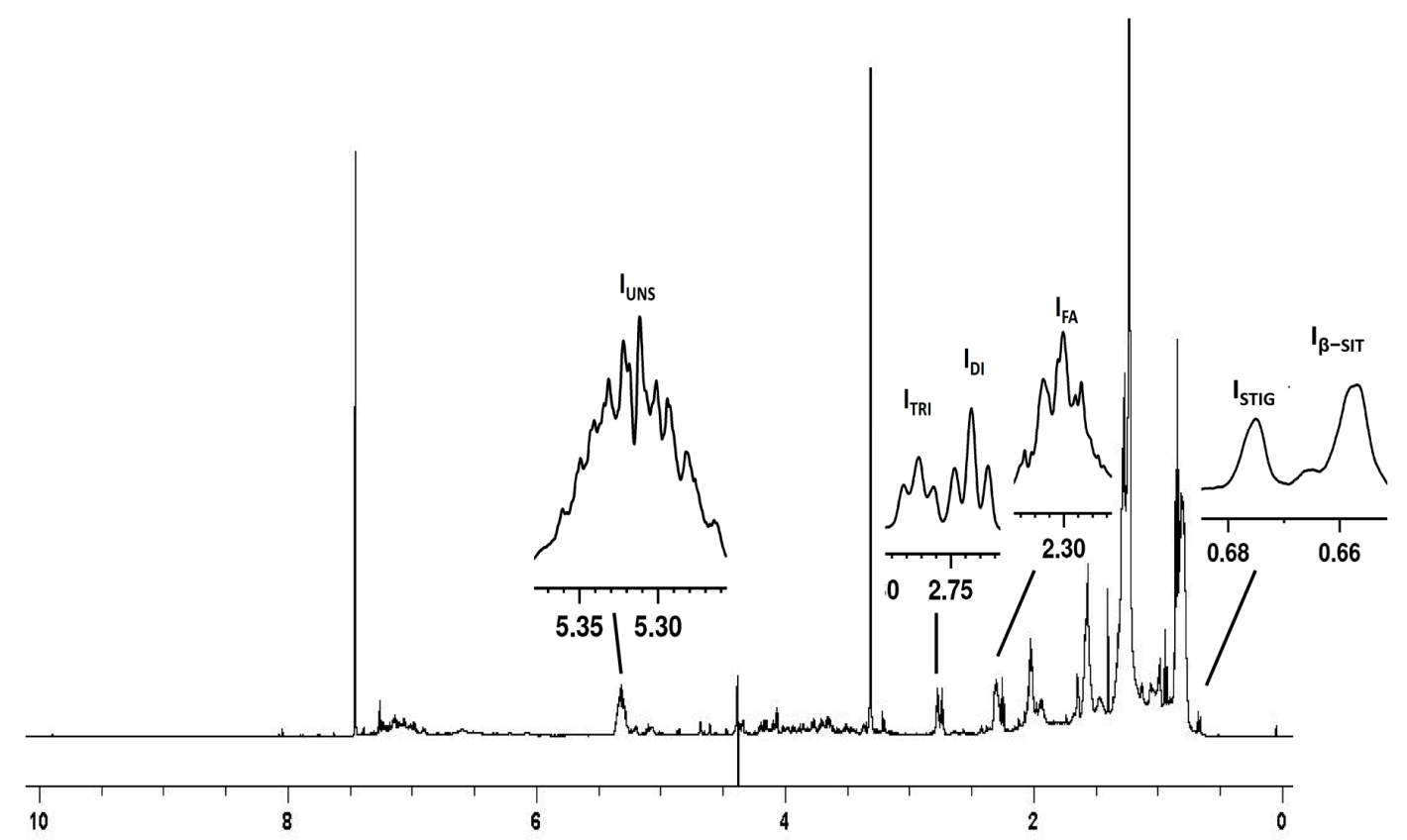

Figure 3. ${ }^{1} \mathrm{H}$ NMR spectrum of organic extract from tomato fruits of "Fiaschetta di Fondi" in $\mathrm{CDCl}_{3} / \mathrm{CD}_{3} \mathrm{OD}$ 2:1 $v / v$ mixture. Signals used for the quantitative analysis have been labelled: $\mathrm{I}_{\beta}$-SIT, $\mathrm{CH}_{3}$, $\beta$-sitosterol; ISTIG, $\mathrm{CH}_{3}$, stigmasterol; $\mathrm{I}_{\mathrm{FA}}, \alpha-\mathrm{CH}_{2}$, all fatty acids; $\mathrm{I}_{\mathrm{DI}}$, diallylic $\mathrm{CH}_{2}$, linoleic acid; $\mathrm{I}_{\text {TRI }}$, diallylic $\mathrm{CH}_{2}$, linolenic acid; I INS, $\mathrm{CH}=\mathrm{CH}$ of all unsaturated fatty acids.

Table 3. Metabolites identified and quantified in the $600.13 \mathrm{MHz}{ }^{1} \mathrm{H}$ spectra $\left(27^{\circ} \mathrm{C}\right)$ of organic extracts from Bamano, DuceMiel, King Creole, Sugarland, and Fiaschetta tomato cultivars.

\begin{tabular}{ccccc}
\hline Compound & Assignment $^{\mathbf{a}}$ & ${ }^{\mathbf{1}} \mathbf{H}(\mathbf{p p m})$ & Multiplicity: $\boldsymbol{J} \mathbf{H z}]$ & ${ }^{{ }^{\mathbf{3}} \mathbf{C}(\mathbf{p p m})}$ \\
\hline Oleic fatty chain & $\mathrm{COO}$ & & & 174.4 \\
$\left(\mathrm{C} 18: 1 \Delta^{9}\right)$ & $\mathrm{CH}_{2}-2$ & 2.30 & & 34.6 \\
& $\mathrm{CH}_{2}-3$ & 1.58 & $\mathrm{~m}$ & 25.3 \\
& $\mathrm{CH}_{2}-4,7$ & 1.30 & $\mathrm{~m}$ & 29.5 \\
& $\mathrm{CH}_{2}-8$ & 2.01 & $\mathrm{~m}$ & 27.6 \\
& $\mathrm{CH}=\mathrm{CH} 9,10$ & 5.31 & $\mathrm{~m}$ & 130.4 \\
& $\mathrm{CH}_{2}-11$ & 2.01 & $\mathrm{~m}$ & 27.6 \\
$\mathrm{CH}_{2}-12,15$ & $1.33-1.30$ & $\mathrm{~m}$ & $29.4-30.2$ \\
& $\mathrm{CH}_{2}-16$ & 1.28 & $\mathrm{~m}$ & 31.9 \\
$\mathrm{CH}_{2}-17$ & 1.26 & $\mathrm{~m}$ & 22.9 \\
& $\mathrm{CH}_{3}-18$ & 0.84 & $\mathrm{t}$ & 14.3 \\
\hline
\end{tabular}


Table 3. Cont.

\begin{tabular}{|c|c|c|c|c|}
\hline Compound & Assignment $^{a}$ & ${ }^{1} \mathrm{H}(\mathrm{ppm})$ & Multiplicity: $J[\mathrm{~Hz}]$ & ${ }^{13} \mathrm{C}$ (ppm) \\
\hline $\begin{array}{l}\text { Di-unsaturated fatty } \\
\text { acids (DUFA) }\end{array}$ & $\mathrm{COO}$ & & & 174.4 \\
\hline $\begin{array}{l}\text { Linoleic fatty chain } \\
\quad\left(\mathrm{C} 18: 2 \Delta^{9,12}\right)\end{array}$ & $\begin{array}{c}\mathrm{CH}_{2}-2 \\
\mathrm{CH}_{2}-3 \\
\mathrm{CH}_{2}-4,7 \\
\mathrm{CH}_{2}-8 \\
\mathrm{CH}-9 \\
\mathrm{CH}-10 \\
\mathrm{CH}_{2}-11 \\
\mathrm{CH}-12 \\
\mathrm{CH}-13 \\
\mathrm{CH}_{2}-14 \\
\mathrm{CH}_{2}-15 \\
\mathrm{CH}_{2}-16 \\
\mathrm{CH}_{2}-17\end{array}$ & $\begin{array}{c}2.30 \\
1.58 \\
1.32-1.28 \\
2.02 \\
5.33 \\
5.30 \\
2.73 \\
5.30 \\
5.33 \\
2.02 \\
1.27 \\
1.27 \\
1.23 \\
0.85\end{array}$ & $\begin{array}{c}\mathrm{m} \\
\mathrm{m} \\
\mathrm{m} \\
\mathrm{m} \\
\mathrm{m} \\
\mathrm{t}[6.8] \\
\mathrm{m} \\
\mathrm{m} \\
\mathrm{m} \\
\mathrm{m} \\
\mathrm{m} \\
\mathrm{m}\end{array}$ & $\begin{array}{c}34.6 \\
25.3 \\
29.5 \\
27.6 \\
130.4 \\
128.6 \\
26.0 \\
128.6 \\
130.4 \\
27.6 \\
29.4 \\
31.6 \\
22.9 \\
14.3\end{array}$ \\
\hline $\begin{array}{l}\text { Tri-unsaturated fatty } \\
\text { acids (TUFA) }\end{array}$ & $\begin{array}{c}\mathrm{CH}_{3}-18 \\
\mathrm{COO}\end{array}$ & 0.85 & $t$ & 174.4 \\
\hline $\begin{array}{l}\text { Linolenic fatty chain } \\
\qquad\left(\mathrm{C} 18: 3 \Delta^{9,12,15}\right)\end{array}$ & $\begin{array}{c}\mathrm{CH}_{2}-2 \\
\mathrm{CH}_{2}-3 \\
\mathrm{CH}_{2}-4,7 \\
\mathrm{CH}_{2}-8 \\
\mathrm{CH}-9 \\
\mathrm{CH}-10 \\
\mathrm{CH}_{2} 11 \\
\mathrm{CH}=\mathrm{CH} 12,13 \\
\mathrm{CH}_{2}-14 \\
\mathrm{CH}-15 \\
\mathrm{CH}-16 \\
\mathrm{CH}_{2}-17 \\
\mathrm{CH}_{3}-18\end{array}$ & $\begin{array}{l}2.30 \\
1.58 \\
1.30 \\
2.03 \\
5.33 \\
5.30 \\
2.77 \\
5.30 \\
2.77 \\
5.27 \\
5.35 \\
2.04 \\
0.94\end{array}$ & $\begin{array}{c} \\
\mathrm{m} \\
\mathrm{m} \\
\mathrm{m} \\
\mathrm{m} \\
\mathrm{m} \\
\mathrm{t}[6.2] \\
\mathrm{m} \\
\mathrm{t}[6.2] \\
\mathrm{m} \\
\mathrm{m} \\
\mathrm{m} \\
\mathrm{t}[7.6]\end{array}$ & $\begin{array}{c}34.6 \\
25.3 \\
29.5 \\
27.6 \\
130.4 \\
128.6 \\
26.0 \\
128.6 \\
26.0 \\
127.4 \\
132.2 \\
20.9 \\
14.4\end{array}$ \\
\hline $\begin{array}{l}\text { Diacylglycerol } \\
\text { moiety }\end{array}$ & $\begin{array}{l}\mathrm{CH}_{2}-\mathrm{sn} 1 \\
\mathrm{CH}-\mathrm{sn} 2 \\
\mathrm{CH}_{2}-\mathrm{sn} 3\end{array}$ & $\begin{array}{c}4.34 ; 4.16 \\
5.20 \\
4.07\end{array}$ & $\mathrm{~m}$ & $\begin{array}{l}62.6 \\
70.2 \\
64.7\end{array}$ \\
\hline $\begin{array}{c}\text { Saturated fatty acids } \\
\text { (SFA) }\end{array}$ & $\mathrm{COO}$ & & & 174.4 \\
\hline & $\begin{array}{c}\mathrm{CH}_{2}-2 \\
\mathrm{CH}_{2}-3 \\
\mathrm{CH}_{2} \\
\mathrm{CH}_{2} \mathrm{n}-1 \\
\mathrm{CH}_{3} \mathrm{n}\end{array}$ & $\begin{array}{c}2.28 \\
1.58 \\
1.28-1.22 \\
1.26 \\
0.84\end{array}$ & $\begin{array}{l}\mathrm{m} \\
\mathrm{m} \\
\mathrm{t}\end{array}$ & $\begin{array}{c}34.6 \\
25.3 \\
29.6-32.0 \\
22.9 \\
14.2\end{array}$ \\
\hline$\beta$-Sitosterol & $\mathrm{CH}_{3}-18$ & 0.66 & $\mathrm{~s}$ & 12.2 \\
\hline Stigmasterol & $\begin{array}{c}\mathrm{CH}_{3}-18 \\
\mathrm{CH}=\mathrm{CH}-22,23\end{array}$ & $\begin{array}{c}0.68 \\
5.12 ; 4.99\end{array}$ & $\mathrm{~s}$ & 12.2 \\
\hline & $\mathrm{CH}(\mathrm{OH})-3$ & 3.50 & & 71.7 \\
\hline Squalene & $\begin{array}{l}\mathrm{CH}_{3}-\mathrm{a} \\
\mathrm{CH}_{3}-\mathrm{b} \\
\mathrm{CH}-\mathrm{c} \\
\mathrm{CH}_{2}-\mathrm{d} \\
\mathrm{CH}_{2}-\mathrm{e}\end{array}$ & $\begin{array}{l}1.56 \\
1.64 \\
5.07 \\
2.03 \\
1.94\end{array}$ & $\mathrm{~m}$ & $\begin{array}{c}16.2 \\
25.8 \\
124.7 \\
27.4 \\
40.1\end{array}$ \\
\hline Phosphatidylcholine & $\mathrm{N}\left(\mathrm{CH}_{3}\right)_{3}$ & 3.21 & s & 54.5 \\
\hline
\end{tabular}

${ }^{\mathrm{a}}$ For structure fragment numbering see [33].

The results of quantitative analysis, reported as histograms in Figure 4, pointed out some interesting differences between the investigated tomatoes cultivars. The amount of $\beta$-sitosterol changed from $3.1 \%$ (Fiaschetta) to $5.9 \%$ (Bamano), whereas stigmasterol ranged from $0.7 \%$ in King Creole to $1.8 \%$ in Bamano cultivar. The total concentration of unsaturated fatty acids (UFA) is very close in all the selected tomato fruits; it varies from 51.7\% in Bamano to $65.8 \%$ in Fiaschetta. In terms of mono-unsaturated fatty acids (MUFA), Fiaschetta cultivar was found to be the richest one $(24.7 \%)$, whereas Sugarland 
and Bamano (15.9 and 16.5\%, respectively) were characterized by the lowest contents. Di-unsaturated fatty acids (DUFA) level (linoleic acid) was comparable in the five cultivars ranging from $24.7 \%$ in King Creole to $30.7 \%$ in DulceMiel, whereas tri-unsaturated fatty acid content (TUFA, linolenic acid) was found to be nearly doubled in King Creole (15.96\%) compared to Bamano (8.9\%) which was characterized by the lowest content.
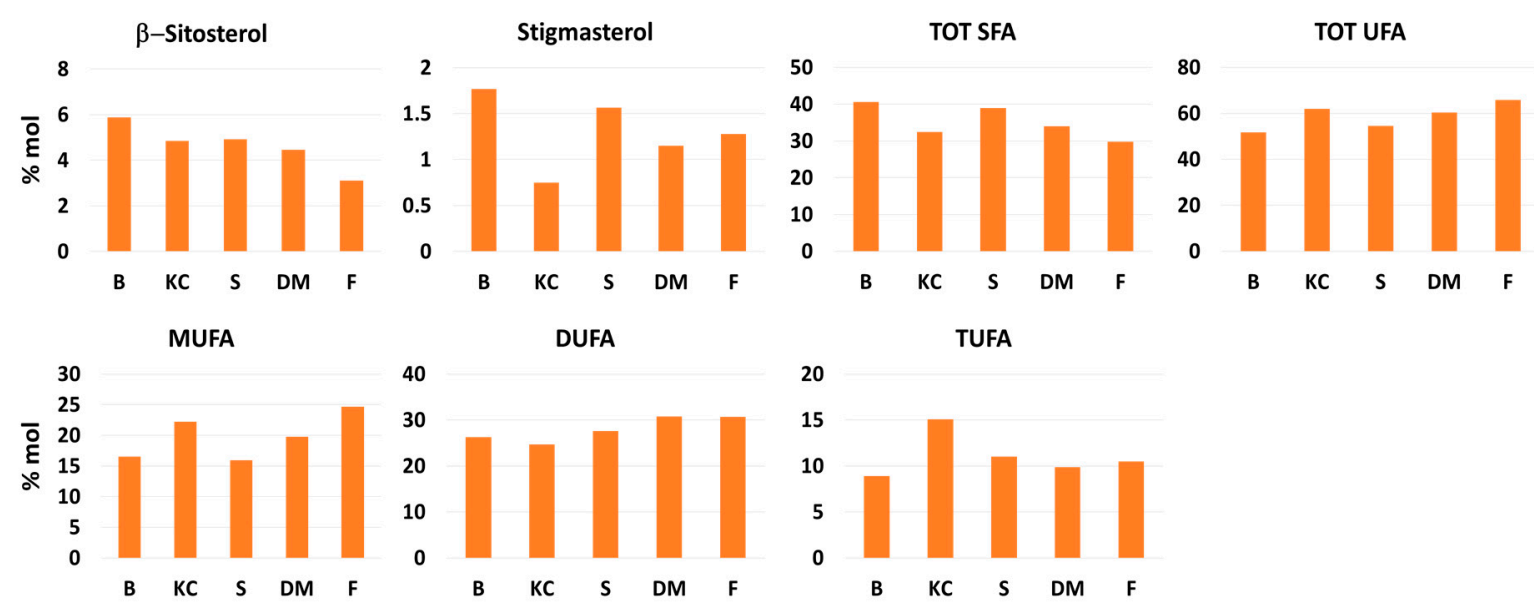

Figure 4. Histograms comparing the concentration (\% molar) of metabolites present in tomato organic extracts from the investigated five cultivars (B: Bamano, KC: King Creole, S: Sugarland, DM: DulceMiel, F: Fiaschetta).

\subsection{Hydroalcoholic and Organic Fractions: A Comparison Among Cultivars}

NMR data including all the quantified metabolites from both hydroalcoholic and organic fractions were submitted to tree cluster analysis (TCA) to point out general similarities/differences in the metabolite profile of the investigated cultivars (Figure 5). The first level of the dendrogram showed two clusters: the first cluster is composed by Fiaschetta (native) and DulceMiel (hybrid) cultivars, and the second one includes the three remaining hybrid cultivars. Cutting the dendrogram at a lower level the previous second cluster is further divided in two groups: one consisting of King Creole cultivar and the other one consisting of the remaining two hybrid cultivars, Bamano and Sugarland.

DulceMiel and Fiaschetta are clearly distinguished from the rest, having, as shown in the histograms of Figure 2, the highest levels of the most abundant amino acids namely glutamic acid, glutamine, alanine, GABA, and aspartic acid as well as citric and lactic acids. Moreover, both the cultivars have comparable amounts of citric and malic acids, aspartic acid, phenylalanine, threonine, valine, choline, stigmasterol, DUFA, and TUFA. A significant difference between these two cultivars is the carbohydrate profile: higher levels of glucose, fructose, and galactose were found in DulceMiel than in Fiaschetta, the latter being characterized by the lowest content of sugars among all cultivars.

King Creole, Bamano, and Sugarland belong to the second TCA cluster. They were characterized by the lowest content of many hydroalcoholic metabolites. However, it is important to note that King Creole showed the highest content of malic acid. Bamano and Sugarland showed a very similar chemical composition, being characterized by high levels of glucose, fructose, and galactose. In fact, the producers declare these two cultivars to be the sweetest compared to the others, likely due to a balance between acids and sugars in favor of the last ones. Bamano and Sugarland were similar also in terms of organic extracts composition: higher levels of sterols ( $\beta$-sitosterol and stigmasterol) and SFA, and lower levels of UFA (in particular MUFA) were found in both tomato fruits. 


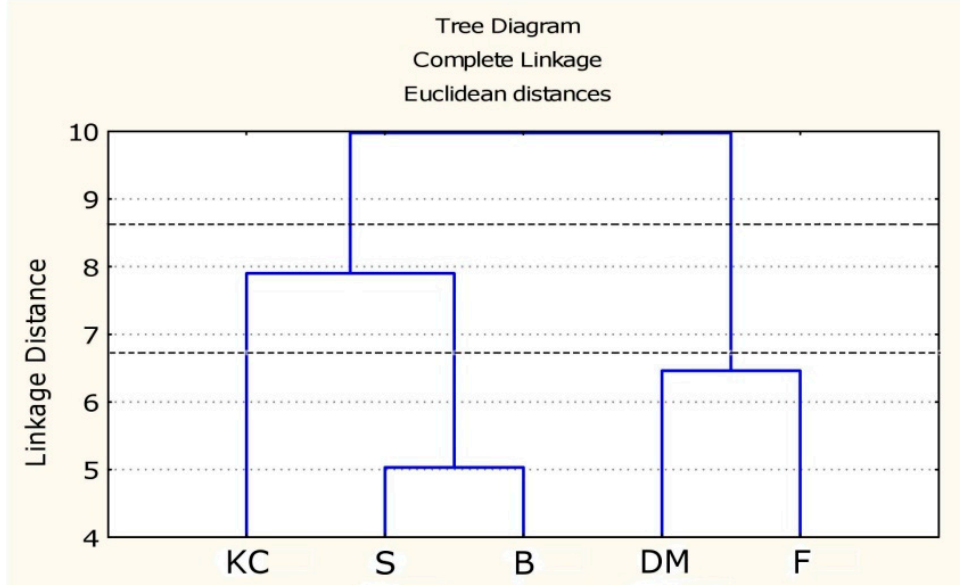

Figure 5. Dendrogram (TCA) showing the clustering, based on NMR data (both hydroalcoholic and organic metabolites quantified) of F: Fiaschetta, B: Bamano, DM: DulceMiel, S: Sugarland, KC: King Creole. Two levels corresponding to a different number of groups are marked.

\section{Conclusions}

The NMR-based characterization allowed to obtain the metabolite profiling of hybrid tomato cultivars essential to define nutritional properties. This untargeted approach allowed to characterize each cultivar: King Creole showed the highest content of malic acid, whereas Bamano and Sugarland were characterized by high levels of glucose and fructose. Fiaschetta native cultivar showed the highest level of lactic acid and MUFA and the lowest levels of sugars, whereas DulceMiel cultivar was characterized by high levels of both sugars and acids. The content of water-soluble metabolites in analyzed tomatoes is generally consistent with the literature data obtained by NMR-based characterization of other tomato cultivars ("Ailsa Craig" [17], "Palmiro" and "Clotilde" [10], "Moneymaker" [12]). Nevertheless, a few metabolites showed either relatively lower (malic acid) or higher content (alanine, threonine) with respect to the literature data mentioned above.

The knowledge of the nutritional profile and chemical composition of hybrid tomatoes may represent an important tool for fresh market, industries and customers, driving them to a more targeted and optimized use of the fruits.

Supplementary Materials: The following are available online at http://www.mdpi.com/2076-3417/10/5/1887/s1, Figure S1: ${ }^{1} \mathrm{H}_{-}{ }^{1} \mathrm{H}$ TOCSY spectrum of hydroalcoholic extract from "Fiaschetta di Fondi" tomato fruits in $400 \mathrm{mM}$ phosphate buffer/ $\mathrm{D}_{2} \mathrm{O} 1 \mathrm{mM}$ TSP, Figure S2: ${ }^{1} \mathrm{H}^{-13} \mathrm{C}$ HSQC spectrum of hydroalcoholic extract from "Fiaschetta di Fondi" tomato fruits in $400 \mathrm{mM}$ phosphate buffer/ $\mathrm{D}_{2} \mathrm{O} 1 \mathrm{mM}$ TSP, Figure S3: ${ }^{1} \mathrm{H}^{13} \mathrm{C}$ HMBC spectrum of hydroalcoholic extract from "Fiaschetta di Fondi" tomato fruits in $400 \mathrm{mM}$ phosphate buffer/ $\mathrm{D}_{2} \mathrm{O} 1 \mathrm{mM}$ TSP, Figure S4: ${ }^{1} \mathrm{H}-{ }^{1} \mathrm{H}$ TOCSY spectrum of organic extract from "Fiaschetta di Fondi" tomato fruits in $\mathrm{CDCl}_{3} / \mathrm{CD}_{3} \mathrm{OD}$ 2:1 v/v mixture, Figure S5: ${ }^{1} \mathrm{H}_{-}{ }^{13} \mathrm{C}$ HSQC spectrum of organic extract from "Fiaschetta di Fondi" tomato fruits in $\mathrm{CDCl}_{3} / \mathrm{CD}_{3} \mathrm{OD}$ 2:1 v/v mixture, Figure S6: ${ }^{1} \mathrm{H}_{-}{ }^{13} \mathrm{C}$ HMBC spectrum of organic extract from "Fiaschetta di Fondi" tomato fruits in $\mathrm{CDCl}_{3} / \mathrm{CD}_{3} \mathrm{OD} 2: 1 \mathrm{v} / \mathrm{v}$ mixture.

Author Contributions: Conceptualization, A.P.S. and C.I.; methodology, A.P.S.; validation, A.P.S. and M.S.; formal analysis, C.I., S.C. and M.S.; investigation, C.I. and M.S.; resources, A.M.G.; data curation, A.M.G.; writing —original draft preparation, C.I.; writing—review and editing, A.P.S.; visualization, C.I., L.M. and A.P.S.; supervision, L.M. and A.P.S.; project administration, L.M.; funding acquisition, L.M. All authors have read and agreed to the published version of the manuscript.

Funding: This work has been supported by REGIONE LAZIO, “e-ALIERB” Project LR13/2008-Dipartimento di Chimica e Tecnologie del Farmaco, Sapienza Università di Roma and by Italian Ministry of Education, Universities and Research-Dipartimenti di Eccellenza-L. 232/2016

Acknowledgments: The authors acknowledge Terra del Sole farm for the samples collection.

Conflicts of Interest: The authors declare no conflict of interest. The funders had no role in the design of the study; in the collection, analyses, or interpretation of data; in the writing of the manuscript, or in the decision to publish the results. 


\section{References}

1. FAOSTAT. Available online: http://www.fao.org/faostat/en/\#home (accessed on 20 January 2020).

2. Atanassova, B.; Georgiev, H. Expression of heterosis by hybridization. In Genetic Improvement of Solanaceous Crop Volume 2: Tomatoes; Razdan, M.K., Mattoo, A.K., Eds.; CRC Press: Boca Raton, FL, USA, 2006; pp. $113-151$.

3. Duvick, D.N. Commercial strategies for exploiting heterosis. In Proceedings of the International Symposium "The Genetics and Exploitation of Heterosis in Crops", Mexico City, Mexico, 17-22 August 1997; pp. $206-207$.

4. Malmendal, A.; Amoresano, C.; Trotta, R.; Lauri, R.; De Tito, S.; Novellino, E.; Randazzo, A. NMR spectrometers as "Magnetic Tongues": Prediction of sensory descriptors in canned tomatoes. J. Agric. Food Chem. 2011, 59, 10831-10838. [CrossRef]

5. Sánchez Pérez, E.M.; López, J.G.; Iglesias, M.J.; Ortiz, F.L.; Toresano, F.; Camacho, F. HRMAS-nuclear magnetic resonance spectroscopy characterization of tomato "flavor varieties" from Almería. Food Res. Int. 2011, 44, 3212-3221. [CrossRef]

6. Oruna-Concha, M.-J.; Methven, L.; Blumenthal, H.; Young, C.; Mottram, D.S. Differences in Glutamic acid and 5-Ribonucleotide contents between flesh and pulp of tomatoes and the relationship with umami taste. J. Agric. Food Chem. 2007, 55, 5776-5780. [CrossRef]

7. Mannina, L.; Sobolev, A.P.; Viel, S. Liquid state ${ }^{1} \mathrm{H}$ high field NMR in food analysis. Prog. Nucl. Magn. Res. Spectr. 2012, 66, 1-39. [CrossRef] [PubMed]

8. Sobolev, A.P.; Thomas, F.; Donarski, J.; Ingallina, C.; Circi, S.; Cesare Marincola, F.; Capitani, D.; Mannina, L. Use of NMR applications to tackle future food fraud issues. Trends Food Sci. Technol. 2019, 91, 347-353. [CrossRef]

9. Masetti, O.; Ciampa, A.; Nisini, L.; Sequi, P.; Dell'Abate, M.T. A multifactorial approach in characterizing geographical origin of Sicilian cherry tomatoes using ${ }^{1} \mathrm{H}-\mathrm{NMR}$ profiling. Food Res. Int. 2017, 100, 623-630. [CrossRef] [PubMed]

10. Deborde, C.; Maucourt, M.; Baldet, P.; Bernillon, S.; Biais, B.; Talon, G.; Ferrand, C.; Jacob, D.; Ferry-Dumazet, H.; de Daruvar, A.; et al. Proton NMR quantitative profiling for quality assessment of greenhouse-grown tomato fruit. Metabolomics 2009, 5, 183-198. [CrossRef]

11. Sobolev, A.P.; Segre, A.L.; Lamanna, R. Proton high-field NMR study of tomato juice. Magn. Reson. Chem. 2003, 41, 237-245. [CrossRef]

12. Jézéquel, T.; Deborde, C.; Maucourt, M.; Zhendre, V.; Moing, A.; Giraudeau, P. Absolute quantification of metabolites in tomato fruit extracts by fast 2D NMR. Metabolomics 2015, 11, 1231-1242. [CrossRef]

13. Tiziani, S.; Schwartz, S.J.; Vodovotz, Y. Profiling of carotenoids in tomato juice by one- and two-dimensional NMR. J. Agric. Food Chem. 2006, 54, 6094-6100. [CrossRef]

14. Masetti, O.; Ciampa, A.; Nisini, L.; Valentini, M.; Sequi, P.; Dell'Abate, M.T. Cherry tomatoes metabolomic profile determinated by ${ }^{1} \mathrm{H}$-High Resolution-NMR spectroscopy as influenced by growing season. Food Chem. 2014, 162, 215-222. [CrossRef] [PubMed]

15. Mattoo, A.K.; Sobolev, A.P.; Neelam, A.; Goyal, R.K.; Handa, A.K.; Segre, A.L. Nuclear magnetic resonance spectroscopy-based metabolite profiling of transgenic tomato fruit engineered to accumulate spermidine and spermine reveals enhanced anabolic and nitrogen-carbon interactions. Plant Physiol. 2006, 142, 1759-1770. [CrossRef] [PubMed]

16. Sańchez Perez, E.M.; Iglesias, M.J.; López Ortiz, F.; Sańchez Perez, I.; Maŕtinez Galera, M. Study of the suitability of HRMAS NMR for metabolic profiling of tomatoes: Application to tissue differentiation and fruit ripening. Food Chem. 2010, 122, 877-887. [CrossRef]

17. Mounet, F.; Lemaire-Chamley, M.; Maucourt, M.; Carbasson, C.; Giraudel, J.L.; Deborde, C.; Lessire, R.; Gallusci, P.; Betrand, W.; Gaudilleŕe, M.; et al. Quantitative metabolic profiles of tomato flesh and seeds during fruit development: Contemporary analysis with ANN and PCA. Metabolomics 2007, 3, 273-288. [CrossRef]

18. Sobolev, A.P.; Circi, S.; Capitani, D.; Ingallina, C.; Mannina, L. Molecular fingerprint in food authenticity. Curr. Opin. Food Sci. 2017, 16, 59-66. [CrossRef]

19. Circi, S.; Capitani, D.; Randazzo, A.; Ingallina, C.; Mannina, L.; Sobolev, A.P. Panel test and chemical analyses of commercial olive oils: A comparative study. Chem. Biol. Technol. Agric. 2017, 4, 1-10. [CrossRef]

20. Hohmann, M.; Christoph, N.; Wachter, H.; Holzgrabe, U. ${ }^{1}$ H-NMR Profiling as an approach to differentiate conventionally and organically grown tomatoes. J. Agric. Food Chem. 2014, 62, 8530-8540. [CrossRef] 
21. Sobolev, A.P.; Neelam, A.; Fatima, T.; Shukla, V.; Handa, A.K.; Mattoo, A.K. Genetic introgression of ethylene-suppressed transgenic tomatoes with higher-polyamines trait overcomes many unintended effets due to reduced ethylene on the primary metabolome. Front. Plant Sci. 2014, 5, 632. [CrossRef]

22. Neelam, A.; Cassol, T.; Mehta, R.A.; Abdul-Baki, A.A.; Sobolev, A.P.; Goyal, R.K.; Abbott, J.; Segre, A.L.; Handa, A.K.; Mattoo, A.K. A field-grown transgenic tomato line expressing higher levels of polyamines reveals legume cover crop mulch-specific perturbations in fruit phenotype at the levels of metabolite profiles, gene expression, and agronomic characteristics. J. Exp. Bot. 2008, 59, 2337-2346. [CrossRef]

23. Capitani, D.; Sobolev, A.P.; Delfini, M.; Vista, S.; Antiochia, R.; Proietti, N.; Bubici, S.; Ferrante, G.; Carradori, S.; De Salvador, F.R.; et al. NMR methodologies in the analysis of blueberries. Electrophoresis 2014, 35, 1615-1626. [CrossRef]

24. Sobolev, A.P.; Mannina, L.; Capitani, D.; Sanzò, G.; Ingallina, C.; Botta, B.; Fornarini, S.; Crestoni, M.E.; Chiavarino, B.; Carradori, S.; et al. A multi-methodological approach in the study of Italian PDO "Cornetto di Pontecorvo" red sweet pepper. Food Chem. 2018, 255, 120-131. [CrossRef] [PubMed]

25. Romersurg, H.C. Cluster Analysis for Researchers; Lulu Press: Morrisville, NC, USA, 2004.

26. Agius, C.; von Tucher, S.; Poppenberger, B.; Rozhon, W. Quantification of glutamate and aspartate by ultra-high-performance liquid chromatography. Molecules 2018, 23, 1389. [CrossRef] [PubMed]

27. Boggio, S.B.; Palatnik, J.F.; Heldt, H.W.; Valle, E.M. Changes in amino acid composition and nitrogen metabolizing enzymes in ripening fruits of Lycopersicon esculentum Mill. Plant Sci. 2000, 159, 125-133. [CrossRef]

28. Sorrequieta, A.; Ferraro, G.; Boggio, S.B.; Valle, E.M. Free amino acid production during tomato fruit ripening a focus on L-glutamate. Amino Acids 2010, 38, 1523-1532. [CrossRef]

29. Schauer, N.; Zamir, D.; Fernie, A.R. Metabolic profiling of leaves and fruit of wild species tomato: A survey of the Solanum lycopersicum complex. J. Exp. Bot. 2005, 56, 297-307. [CrossRef]

30. Mallamace, D.; Corsaro, C.; Salvo, A.; Cicero, N.; Macaluso, A.; Giangrosso, G.; Ferrantelli, V.; Dugo, G. A multivariate statistical analysis coming from the NMR metabolic profile of cherry tomatoes (The Sicilian Pachino case). Phys. A 2014, 401, 112-117. [CrossRef]

31. Bartkiene, E.; Vidmantiene, D.; Juodeikiene, G.; Viskelis, P.; Urbonaviciene, D. Lactic acid fermentation of tomato: Effects on cis/trans lycopene isomer ratio, beta-carotene mass fraction and formation of $\mathrm{L}(+)-$ and D(-)-lactic acid. Food Technol. Biotechnol. 2013, 51, 471-478.

32. Wu, J.-j.; Du, R.-p.; Gao, M.; Sui, Y.-q.; Xiu, L.; Wang, X. Naturally occurring lactic acid bacteria isolated from tomato pomace silage. Asian Australas J. Anim. Sci. 2014, 27, 648-657. [CrossRef]

33. Sobolev, A.P.; Brosio, E.; Gianferri, R.; Segre, A.L. Metabolic profile of lettuce leaves by high-field NMR spectra. Magn. Reson. Chem. 2005, 43, 625-638. [CrossRef] 